\title{
FORMULASI TABLET EKSTRAK KANGKUNG AIR (Ipomoea aquatica F.) DENGAN VARIASI KADAR AMILUM MANIHOT SEBAGAI BAHAN PENGHANCUR
}

\author{
Sutrisna Khaidir ${ }^{1}$, Mimiek Murrukmihadi ${ }^{2}$, Aris Perdana Kusuma ${ }^{1 *}$ \\ ${ }^{1}$ Program Studi Farmasi Universitas Islam Indonesia \\ ${ }^{2}$ Fakultas Farmasi Universitas Gadjah Mada \\ *email: kusuma.health@yahoo.com
}

\begin{abstract}
ABSTRAK
Kangkung air (Ipomoea aquatica F.) merupakan tanaman yang mempunyai efek hipoglikemik. Kangkung air diformulasikan menjadi bentuk sediaan tablet untuk menghasilkan manfaat dari segi kepraktisan dan ketepatan dosis terapi. Bahan penghancur sangat berperan terhadap kecepatan pelepasan zat aktif dari tablet sehingga efek obat dapat segera dirasakan oleh pasien diabetes. Tujuan penelitian ini adalah untuk mengetahui waktu hancur tablet ekstrak kangkung air dengan variasi kadar bahan penghancur amilum manihot, dan mengetahui kadar penghancur terbaik sesuai dengan hasil evaluasi sifat fisik tabletnya. Ekstrak kangkung air diperoleh dari proses maserasi dengan etanol 96\%, kemudian dipekatkan dengan rotary evaporator. Ekstrak di uji secara kualitatif dengan KLT dengan fase gerak petroleum eter : aseton : dietil amin dengan perbandingan (10:4:1), fase diam silika gel $\mathrm{F}_{254}$ menghasilkan nilai $\mathrm{Rf}$ sebesar 0,625. Tablet dibuat dengan metode granulasi basah dengan bahan penghancur amilum manihot $10 \%$, $15 \%$ dan $20 \%$. Sifat fisik granul yang diuji meliputi waktu alir, sudut diam dan indeks kompresibilitas. Tablet diuji sifat fisik meliputi keseragaman bobot, keseragaman ukuran, kekerasan, kerapuhan dan waktu hancur. Hasil penelitian menunjukkan bahwa variasi kadar amilum manihot mempercepat waktu hancur tablet. Formula optimum dicapai pada kadar amilum manihot $15 \%$.
\end{abstract}

Kata kunci : amilum manihot, bahan penghancur, Ipomoea aquatica Forsk

\section{ABSTRACT}

Ipomoea aquatica $\mathrm{F}$. are plant that has a hypoglycemic effect. Ipomoea aquatica F. was formulated into tablet dosage forms to produce benefits in terms of practicality and accuracy of therapeutic doses.Disintegrant has effect to release the active substance rate of the tablet so that drug effects can be felt by patients with diabetic immediatly. The purpose of this study was to determine disintegration time of Ipomoea aquatica F. extract tablets with various levels of amilum manihot and determine the best concentration of amilum manihot based on the evaluation of physical properties of tablets.Ipomoea aquatica F. extracts was obtained from the maceration using $96 \%$ ethanol, than concentrated by rotary evaporator. The extracts were tested qualitatively by TLC with petroleum eter: aceton: dietil amin mobile phase (10:4:1), the phase silica gel $F_{254}$ with $R f$ value about 0,625 . Tablets were formulated with amilum manihot concentration variation of $10 \%$, $15 \%$ and $20 \%$ by wet granulation method. Physical properties of granules were tested such as powder flow, angle of repose, porosity and compressibility index.Tablets were tested to know physical properties such as weight uniformity, sizeuniformity, hardness, friability and disintegration time.The results showed that variaton levels of amilum manihot decrease disintegration time. Variation of amilum manihot was affected in disintegration time, and the optimumt formula with was achieved by $15 \%$ amilum manihot.

Keywords : amilum manihot, disintegrant, Ipomoea aquatica Forsk 


\section{PENDAHULUAN}

Berbagai pengobatan untuk mencegah dan mengatasi diabetes telah dikembangkan, termasuk pula penggunaan berbagai macam herbal. Salah satu herbal yang memiliki aktivitas sebagai antihiperglikemia adalah kangkung air (Ipomoea aquatica F.) (Malalavidhane et al., 2003).

Kangkung merupakan tanaman yang kaya akan katorenoid dan klorofil. Kandungan kangkung sebagian besar mengandung asam amino esensial seperti asam aspartat, glisin, alanin dan leusin sesuai dengan pola diet protein yang direkomedasikan oleh WHO (Shekhar, 2011).

Penambahan bahan penghancur ditambahkan untuk memudahkan pecahnya atau hancurnya tablet karena bahan dapat berfungsi menarik air ke dalam tablet, mengembang dan menyebabkan tablet pecah menjadi bagian-bagiannya. Amilum manihot dipilih sebagai bahan penghancur dalam penelitian ini karena selain memiliki sifat penghancur yang baik, namun juga mudah didapatkan dengan harga yang terjangkau dan juga dapat diproduksi sendiri karena berasal dari bahan alam (Depkes RI, 1995).

Amilum manihot merupakan bahan penghancur yang sifatnya inert dan dapat meninggikan porositas dalam pembuatan tablet sehingga memudahkan penetrasi air lewat pori-pori ke dalam bagian tablet dan akan mempercepat hancurnya tablet (Hariana, 2007).

\section{METODE PENELITIAN}

Bahan yang digunakan dalam penelitian ini yaitu ekstrak yang dihasilkan dari kangkung air \{(Ipomoeaaquatiqa Forsk) yang diperoleh dari petani kangkung di daerah Jalan Telogo Adi, Sleman, DIY\}, Ceolus PH 101, Povidon $\mathrm{K} 30$, amilum manihot, magnesium stearat, etanol $96 \%$, petroleum eter, aseton, dietil amin, silika gel, anisaldehid asam sulfat.

Alat-alat yang digunakan dalam penelitian ini yaitu alat maserasi, corong Buchner, evaporator (Heidolph), ayakan mesh 16 dan 18, mesin kempa tablet single punch, neraca analitik (Metler Toledo), seperangkat alat uji sudut diam, alat uji hardness tester (Vanguard), alat uji kerapuhan tablet (Erweka), serta alat uji disintegrasi tablet (Erweka).

Penelitian ini diawali dengan melakukan determinasi tanaman yang akan diteliti. Determinasi dilakukan untuk mendapatkan kebenaran bahan yang digunakan pada penelitian sehingga menghindari kesalahan dalam pengambilan kandungan senyawa dalam kangkung air (Ipomoea aquatica F.).

Serbuk kering kangkung air dimasukan kedalam bejana maserasi, kemudian ditambahkan pelarut etanol 96\% sampai semua serbuk terendam. Serbuk yang telah terendam etanol dibiarkan selama 24 jam sambil sesekali dilakukan pengadukan, kemudian disaring dengan corong Buchner. Filtrat hasil rendaman diuapkan menggunakan rotary evaporator agar etanol menguap dan menghasilkan ekstrak kental. Ekstrak yang diperoleh setelah proses penyarian selesai selanjutnya dipekatkan diatas water bath pada suhu $60^{\circ} \mathrm{C}$. 
Pembuatan granul dilakukan dengan mencampurkan ekstrak kental kangkung air dengan bahan pengisi Ceolus pH 101, kemudian diayak dengan ayakan no 16 . Campuran tersebut kemudian dikeringkan dalam almari pengering dengan suhu $60^{\circ} \mathrm{C}$. Setelah kering granul diayak lagi dengan ayakan no 18, kemudian ditambahkan amilum manihot dan magnesium stearat. Selanjutnya dilakukan uji sifat granul meliputi uji waktu alir, uji sudut diam, dan uji pengetapan.

Granul yang telah diuji sifat fisiknya kemudian dikempa dengan mesin kempa tablet single punch. Bobot masing-masing tablet sebesar $500 \mathrm{mg}$, dikempa dengan tekanan yang sama, kemudian dilakukan uji sifat fisik tablet. Uji sifat fisik tablet meliputi organolepstis, keseragaman bobot, keseragaman ukuran, kekerasan, kerapuhan, dan waktu hancur.

Tabel 1. Formula tablet ekstrak kangkung air menggunakan variasi kadar penghancur amilum Manihot

\begin{tabular}{cccc}
\hline Bahan (mg) & $\begin{array}{c}\text { Formula 1 } \\
\text { Amilum10\% }\end{array}$ & $\begin{array}{c}\text { Formula 2 } \\
\text { Amilum15\% }\end{array}$ & $\begin{array}{c}\text { Formula 3 } \\
\text { Amilum20\% }\end{array}$ \\
\hline Ekstrak & 72 & 72 & 72 \\
Ceolus PH 101 & 363 & 338 & 313 \\
Amilum Manihot & 50 & 75 & 100 \\
Mg stearat & 10 & 10 & 10 \\
Povidon K 30 & 5 & 5 & 5 \\
\hline Total & 500 & 500 & 500 \\
\hline
\end{tabular}

\section{Uji kromatografi lapis tipis}

Prinsip kerja metode KLT adalah "like disolve like" yaitu larutan sampel ditotolkan pada lapis/lempeng tipis yang disebut fase diam kemudian dikembangkan dalam fase gerak terpilih, dengan pengembangan tersebut masing - masing komponen senyawa dalam sampel akan bergerak keatas dengan kecepatan berbeda sesuai dengan tingkat kepolaran tertentu (Sastrohamidjojo, 2005).

Beta karoten adalah senyawa terpene yang tersusun atas 8 unitisoprene yang membentuk cincin pada tiap ujungnya. Rantai panjang dari ikatan ganda terkonyugasi memberikan warna jingga pada berbagai jenis sayuran seperti wortel, labu, aprikot, nektarin, dan lain-lain.

Sistem KLT yang digunakan adalah fase diam silika gel 60 F 254 dan fase gerak petroleum eter: aseton: dietil amin dengan perbandingan (10:4:1) (Mangal et al., 2012). Plat dielusikan hingga batas dan kemudian dikeringkan. Untuk memastikan kandungan zat kimia aktif terpenoid, maka plat yang sudah dielusi kemudian di semprotkan dengan pereaksi anisaldehid asam sulfat dan dipanaskan di oven dengan suhu $100^{\circ} \mathrm{C}$ selama 5-10 menit. Jika timbul warna ungu-merah atau ungu setelah penyemprotan pereaksi anisaldehid asam sulfat menunjukkan adanya terpenoid dalam ekstrak (Marliana, 2007). Pendeteksian bercak dilakukan dibawah sinar UV dengan panjang gelombang $254 \mathrm{~nm}, 366 \mathrm{~nm}$, dan visible.

Identifikasi kandungan senyawa kimia pada ekstrak kangkung air dapat dilakukan dengan mengukur Rf dan dari warna yang dihasilkan setelah penyemprotan pereaksi anisaldehid asam sulfat. Dari gambar kromatogram terlihat bahwa harga $\mathrm{Rf}$ yaitu 0,625. Selain itu, Dengan adanya 
warna ungu pada plat diduga ekstrak kangkung air terdapat senyawa terpenoid. Terpenoid berfluoresensi berwarna ungu-merah atau ungu

\section{HASIL DAN PEMBAHASAN}

\section{Hasil uji sifat fisik granul ekstrak kangkung air (Ipomoea aquatica F.)}

Karakteristik sifat fisik granul tidak hanya mempengaruhi proses penabletan, tetapi juga mempengaruhi kualitas dari tablet itu sendiri. Dalam penelitian ini uji sifat fisik granul yang dilakukan adalah waktu alir, sudut diam, dan pengetapan. Waktu alir menunjukkan mudah atau tidaknya granul mengalir dalam mesin cetak tablet. Baik buruknya waktu alir granul dipengaruhi oleh beberapa faktor yaitu ukuran granul, bentuk granul, dan kelembapan relatif. Granul dengan aliran granul yang kurang baik akan menyebabkan aliran granul dari hopper ke dalam die tidak sempurna, akibatnya bobot tablet yang dihasilkan tidak konstan sehingga setelah penyemprotan pereaksi anisaldehid asam sulfa

akan berpengaruh pada keseragaman zat aktif. Hasil menunjukkan bahwa waktu alir yang di dapat tiap formula baik, karena masuk ke dalam range waktu alir yang disyaratkan untuk granul yang baik yaitu 10 detik (Anonim, 2007).

Dari data hasil penelitian dapat dilihat bahwa formula III menghasilkan waktu alir yang cepat yaitu 4,90 detik sedangkan formula II menghasilkan waktu alir yang lebih lama dibandingkan dengan formula III yaitu 5,06 detik. Sedangkan pada formula I mempunyai waktu alir yang lebih lama yaitu 6,39 detik. Perbedaan hasil dari uji waktu alir dapat disebabkan oleh beberapa faktor yaitu karena perbedaan permukaan granul dari tiap formula yang berbeda.

Tabel 2.Organoleptik ekstrak kental kangkung air

\begin{tabular}{cc}
\hline Parameter & Hasil \\
\hline Warna & Hijau kehitaman \\
Bau & Khas kangkung air \\
Rasa & Pahit \\
Bentuk & Cairan Kental \\
\hline
\end{tabular}

Tabel 3. Hasil pemeriksaan sifat alir granul ekstrak kangkung air

\begin{tabular}{cccc}
\hline Sifat alir & $\begin{array}{c}\text { Formula I } \\
\mathrm{X} \pm \mathrm{SD}\end{array}$ & $\begin{array}{c}\text { Formula II } \\
\mathrm{X} \pm \mathrm{SD}\end{array}$ & $\begin{array}{c}\text { Formula III } \\
\mathrm{X} \pm \mathrm{SD}\end{array}$ \\
\hline Waktu alir (detik) & $6,39 \pm 0,06$ & $5,06 \pm 0,05$ & $4,90 \pm 0,06$ \\
Sudut diam ( $\left.{ }^{\circ}\right)$ & $24,39 \pm 0,97$ & $20,67 \pm 0,43$ & $24,10 \pm 0,13$ \\
Indeks kompresibilitas (\%) & $17,00 \pm 1,00$ & $14,33 \pm 0,57$ & $13,00 \pm 1,00$ \\
Susut pengeringan (\%) & $4,07 \pm 0,13$ & $4,26 \pm 0,29$ & $4,48 \pm 0,29$ \\
\hline
\end{tabular}

Keterangan: Formula I kadar bahan penghancur amilum manihot $10 \%$ Formula II kadar bahan penghancur amilum manihot $15 \%$ Formula III kadar bahan penghancur amilum manihot $20 \%$ 
Sudut diam merupakan sudut yang dibentuk antara tinggi yang terbentuk oleh serbuk atau granul yang telah mendapatkan perlakuan dengan jari-jari yang terbentuk pada landasan serbuk. Serbuk atau granul dapat dikatakan mempunyai sifat alir yang baik apabila sudut diam lebih kecil atau sama dengan $30^{\circ}$ biasanya menunjukkan bahwa bahan dapat mengalir bebas, bila sudutnya lebih besar atau sama dengan $40^{\circ}$ biasanya daya mengalirnya kurang baik. Semakin datar kerucut yang dihasilkan, maka sudut kemiringan semakin kecil, semakin baik sifat aliran serbuk (Harpaz, D., and Mathural, B., 1994).

Dari data hasil penelitian dapat dilihat bahwa formula I memiliki sudut diam $24,39^{\circ}$, dan pada formula II memiliki sudut diam $20,67^{\circ}$, serta pada formula III memiliki sudut diam $24,10^{\circ}$. Berdasarkan teori, sudut diam dipengaruhi oleh besar kecilnya gaya tarik dan gaya gesek antar partikel dan sangat berkaitan dengan proses pengerjaannya dengan sifat alir granul.

Pengetapan menunjukkan penurunan volume granul akibat hentakan dan getaran. Besar kecilnya indeks kompresibilitas dipengaruhi oleh bentuk partikel, ukuran partikel dan distribusi ukuran partikel. Nilai indeks kompresibilitas yang kecil menunjukkan bahwa granul dapat menata diri dengan baik sehingga pada pengetapan tidak memberikan penurunan volume besar. Menurut USP (Fassihi dan Kanfer, 1986), granul atau serbuk dengan indeks kompresibilitas kurang dari $20 \%$ mempunyai sifat alir yang baik.

Untuk hasil yang didapat dari perhitungan indeks kompresibilitas, pada formula I didapatkan hasil sebesar $17 \%$, untuk formula II sebesar $14,33 \%$ dan formula III sebesar $13 \%$. Campuran granul yang memiliki indeks pengetapan (\%T) lebih kecil dari $20 \%$, maka sifat alirnya tergolong baik. Semakin kecil harga \%T maka sifat alirnya akan semakin baik (Fassihi dan Kanfer, 1986). Pada uji pengetapan ini, porositas, kerapatan serta ukuran partikel sangat mempengaruhi kemampuan serbuk untuk menata diri untuk mengisi ruang kosong antar partikel.

Susut pengeringan granul akan mempengaruhi kualitas tablet yang dihasilkan, karena dari sini dapat diketahui tingkat pengeringan granul. Apabila granul yang dihasilkan terlalu basah atau terlalu kering maka akan menyebabkan tablet yang dihasilkan terjadi capping.

Hasil penelitian yang diperoleh dari ketiga formula tersebut yaitu formula I $3,46 \%$, formula II 4,05\%, dan formula III $3,83 \%$. Hal ini dapat diartikan bahwa pengeringan granul sudah maksimal, dan granul sudah mempunyai tingkat kekeringan yang baik yaitu $2 \%-5 \%$. Dari hasil uji susut pengeringan granul ekstrak kangkung air ini maka diharapkanakan mengurangi terjadinya capping pada saat pengempaan.

\section{Sifat fisik tablet ekstrak kangkung air}

Tablet dikempa dan diuji sifat fisiknya pada ruangan dengan kelembapan relatif $40 \%$, hal tersebut untuk menghindari pengaruh kelembapan yang dapat mempengaruhi hasil uji. Tablet yang dihasilkan tiap formula dievaluasi sesegera mungkin untuk menghindari adanya pengaruh dari luar yang dapat mempengaruhi hasil pengujian. Pengujian meliputi uji organoleptik, keseragaman bobot, keseragaman ukuran, kekerasan, kerapuhan, dan waktu hancur. 


\section{Organoleptis tablet}

Pemeriksaan organoleptis merupakan pengenalan awal yang sederhana seobjektif mungkin terhadap tablet. Penampilan umum suatu tablet, sangat penting bagi penerimaan konsumen, maupun pengontrolan keseragaman antar bahan. Warna suatu produk harus seragam dan merata pada suatu tablet. Warna yang tidak merata tidak hanya menyebabkan hilangnya nilai estetik, namun dapat menyebabkan ketidakpercayaan konsumen terhadap keseragaman isi dan rendahnya mutu produk.

Pemeriksaan organoleptis ini dilakukan dengan menggunakan panca indera untuk mendeskripsikan bentuk, warna, bau dan rasa dari ekstrak. Tablet ekstrak kangkung air yang dihasilkan mempunyai karakter fisik yang seragam yaitu berbentuk bulat pipih, tidak retak dan berwarna putih kehitaman, warna ini yang berasal dari campuran warna ekstrak kering kangkung air dan bahan tambahan. Bau dari tablet tetap berbau khas ekstrak, dan berasa sedikit rasa pahit.

Tabel 4. Sifat fisik tablet ekstrak kangkung air

\begin{tabular}{lccc}
\hline \multicolumn{1}{c}{ Hasil Uji } & Formula I & Formula II & Formula II \\
\hline Bobot Rata-Rata (mg) & $606,90 \pm 4,82$ & $608,50 \pm 8,64$ & $611,90 \pm 5,97$ \\
CV (\%) Bobot Rata-Rata & 0,80 & 1,42 & 0,97 \\
Kekerasan (kg) & $5,19 \pm 0,60$ & $5,83 \pm 1,10$ & $6,77 \pm 0,77$ \\
Kerapuhan (\%) & $0,51 \pm 0,17$ & $0,36 \pm 0,13$ & $0,27 \pm 0,02$ \\
Waktu Hancur (menit) & $8,36 \pm 0,19$ & $2,44 \pm 0,05$ & $2,18 \pm 0,06$ \\
Diameter rata-rata (mm) & $13,16 \pm 0,13$ & $13,06 \pm 0,03$ & $13,08 \pm 0,08$ \\
CV (\%) Diameter rata-rata & 1,02 & 0,26 & 0,62 \\
Tebal rata-rata (mm) & $3,96 \pm 0,09$ & $3,70 \pm 0,02$ & $3,65 \pm 0,14$ \\
CV (\%) Tebal rata-rata & 2,37 & 0,70 & 3,99 \\
\hline
\end{tabular}

Keterangan: $n=3$

Formula I kadar bahan penghancur amilum manihot $10 \%$ Formula II kadar bahan penghancur amilum manihot 15\% Formula III kadar bahan penghancur amilum manihot $20 \%$

\section{Keseragaman bobot}

Keseragaman bobot merupakan salah satu parameter baik tidaknya suatu produksi tablet. Uji keseragaman bobot tablet bertujuan untuk melihat apakah tablet yang dicetak mempunyai bobot yang seragam atau tidak. Keseragaman bobot tablet terutama memberikan pengaruh pada keseragaman kandungan zat aktifnya yang akhirnya akan mempengaruhi efek terapi yang dihasilkan. Selama proses produksi tablet, bobot tablet harus diperiksa secara rutin untuk memastikan bahwa bobot tablet yang dihasilkan sesuai dengan yang diinginkan.
Keseragaman bobot antara lain dipengaruhi oleh kecepatan alir granul yang konstan. Semakin mudah granul mengalir maka semakin baik keseragaman bobotnya. Berdasarkan Farmakope Indonesia edisi IV tidak lebih dari dua tablet yang mempunyai penyimpangan bobot lebih dari $5 \%$ dan tidak boleh dari satu tablet pun yang mempunyai penyimpangan lebih dari $10 \%$. Parameter yang digunakan dalam menilai hasil pengujian keseragaman bobot adalah koefisien variasi (CV). Bobot tablet dapat diterima apabila memiliki nilai koefisiensi variasi kurang dari $5 \%$. 
Berdasarkan data hasil penelitian, nilai koefisien variasi (CV) dari ketiga formula kurang dari $2 \%$ yaitu formula I 0,8\%, formula II 1,42\%, dan formula III 0,92\%. Hal ini menunjukkan bahwa ketiga formula tersebut memenuhi persyaratan yaitu nilai koefisien variasi (CV) kurang dari 5\%. Nilai koefisien antar formula yang diperoleh tidak berbeda terlalu jauh karena kecepatan alir massa tablet dari tiap formula hampir seragam. Keseragaman bobot ini menunjukkan bahwa distribusi ukuran partikel bahan-bahan yang terjadi dalam massa tablet homogen. Apabila granul mudah mengisi ruang die dan dengan jumlah yang seragam maka bobot tablet yang dihasilkan akan lebih seragam, sehingga koefisien variasi (CV) menjadi sangat kecil.

\section{Kekerasan}

Uji kekerasan tablet dilakukan untuk ketahanan tablet terhadap tekanan atau goncangan mekanik pada saat pembuatan maupun setelah pembuatan. Kekerasan tablet dipengaruhi oleh tekanan (kompresi) pada saat proses pembuatan tablet, sifat bahan yang dikempa dan jumlah serta jenis bahan pengikat yang digunakan. Semakin besar tekanan yang diberikan saat proses pembuatan tablet, maka akan diperoleh tablet yang semakin tinggi kekerasannya. Peningkatan jumlah bahan pengikat akan meningkatkan kekerasan tablet meskipun tekanan kompresinya sama.

Berdasarkan data hasil penelitian, ratarata kekerasan tablet yang dihasilkan adalah formula I $5,19 \mathrm{~kg} / \mathrm{cm}^{3}$, formula II $5,83 \mathrm{~kg} / \mathrm{cm}^{3}$, formula III 6,77 kg/cm ${ }^{3}$. Hal ini menunjukkan bahwa ketiga formula memenuhi persyaratan, karena persyaratan untuk tablet yang baik yaitu yang memiliki kekerasan antara 4-8 $\mathrm{kg} / \mathrm{cm}^{3}$. Kekerasan ini akan berhubungan dengan waktu hancur dan kerapuhan. Semakin tinggi kekerasan maka semakin rendah kerapuhan tablet, sedangkan semakin tinggi kekerasan maka semakin memperlama waktu hancur obat.

\section{Kerapuhan}

Kerapuhan merupakan parameter yang menggambarkan kekuatan permukaan tablet dalam melawan berbagai perlakuan yang menyebabkan pecah/retak pada permukaan tablet. Semakin besar persentase kerapuhan, maka semakin besar massa tablet yang hilang. Kerapuhan yang tinggi akan mempengaruhi konsentrasi/kadar zat aktif yang masih terdapat pada tablet. Selama proses penabletan dilakukan pengontrolan terhadap kekerasan tablet sehingga kerapuhan tablet yang dihasilkan kurang dari $1 \%$.

Berdasarkan data hasil penelitian menunjukkan bahwa ketiga formula memenuhi persyaratan tablet yang baik yaitu formula I 0,51\%, formula II 0,36\%, formula III $0,27 \%$. Tablet dianggap baik bila memiliki kerapuhan tidak lebih dari $1 \%$.

\section{Waktu Hancur}

Waktu hancur merupakan waktu yang dibutuhkan sejumlah tablet untuk hancur menjadi granul/partikel penyusunnya. Waktu hancur dilakukan untuk menggambarkan lama tablet hancur dalam pencernaan. Semakin besar jumlah air yang masuk ke dalam pori-pori tablet maka jarak antar partikel akan semakin dekat dan tablet akan hancur dalam waktu yang lebih singkat.

Berdasarkan data hasil penelitian, menunjukkan bahwa ketiga formula memiliki waktu hancur kurang dari 15 menit yaitu formula I 8,36 menit, formula II 2,44 menit, formula III 2,18 menit. Hal ini sesuai dengan persyaratan yang tertera dalam Farmakope 
Indonesia edisi IV yang menyatakan bahwa tablet tidak bersalut yang baik memiliki waktu hancur kurang dari 15 menit. Dari data penelitian dapat dilihat bahwa formula III memiliki waktu dengan bahan penghancur amilum manihot $20 \%$ memiliki waktu hancur yang paling cepat, sedangan formula I dengan bahan penghancur amilum manihot $10 \%$ memiliki waktu hancur yang paling lama. Dari data tersebut dapat diambil kesimpulan bahwa semakin tinggi kadar bahan penghancur amilum manihot yang digunakan maka akan semakin cepat pula waktu hancur yang didapatkan.

\section{KESIMPULAN}

Variasi konsentrasi bahan penghancur amilum manihot berpengaruh terhadap sifat fisik tablet. Semakin bertambah konsentrasi penghancur amilum manihot yang digunakan, maka waktu hancur semakin cepat. Amilum manihot sebagai bahan penghancur dapat menghasilkan tablet ekstrak kangkung air dengan daya hancur yang baik pada konsentrasi $15 \%$.

\section{DAFTAR PUSTAKA}

Anonim, 2007, British Pharmacopoeia, Volume IV, London, The Stationary Office on Behalf of Medicine and Healthcare Products Regulatory Agency (MHRA), England, A247, A304, A393 - A397, A405-406
Depkes RI, 1995, Materia Medika Jilid VI, Jakarta : Departemen Kesehatan RI, Hal. 319-325

Fassihi, A.R., dan Kanfer, I., 1986, Effect of Compressibility and Powder Flow Properties On Tablet Weight Variation, Drug Development and IndustrialPharmacy, 11-13, Marcell Dekker Inc, New York. 321-358, 19471966

Hariana, A., 2007, Tumbuhan Obat dan Khasiatnya, Seri 3, Penebar Swadaya, Jakarta, 20-22

Harpaz, D., and Mathural, B., 1994, Handbook of Pharmaceutical Exipients in Wade, Weller P.J., (Eds), Second Edition, The Pharmaceutical Press, London, 425-427

Malalavidhane, T.S., S.M. Wickramasinghe and E.R. Jansz., 2003,. Oral hypoglycemic activity of Ipomoea aquatic in streptozotocin-induced, diabetic wistar rats and type ii diabetes. Phytother. 17, 1098-1100

Mangal, M., Thakral, S., Goswami, M., and Ghai, P., 2012, Superdisintegrant: An Updated Review, International Journal of Pharmacy and Pharmaceutical Science Research, Mastuana Sahib, India

Marliana, Eva., 2007, Analisis Senyawa Metabolit Sekunder dari Batang Spatholobus ferrugineus (Zoll dan Moritzi) Benth yang Berfungsi Sebagai Anti Oksidan, Jurnal Penelitian MIPA, Vol. 1 No. 1 , hal 25

Sastrohamidjojo, H., 2005, Kromatografi, Liberty, Yogyakarta

Shekhar, H. U., 2011. Multi Food Functionalities of Kalmi Shak (Ipomoea aquatica) Grown in Bangladesh. Center for Advanced Research in Sciences, University of Dhaka, Dhaka1000, Bangladesh 